\title{
KELAYAKAN FINANSIAL DAN SENSITIVITAS USAHATANI KOPI ROBUSTA DI DESA KALIBARU MANIS KECAMATAN KALIBARU KABUPATEN BANYUWANGI
}

\author{
FINANCIAL FEASIBILITY AND SENSITIVITY \\ OF ROBUSTA COFFEE FARMING IN KALIBARU MANIS VILLAGE \\ KALIBARU DISTSRICT BANYUWANGI REGENCY
}

\author{
Ati Kusmiati*, Ninik Sumestyo Wati \\ Program Studi Agribisnis Fakultas Pertanian Universitas Jember \\ Jalan Kalimantan Kampus Tegal Boto Jember \\ *E-mail: ati.faperta@unej.ac.id \\ (Diterima 15-10-2019; Disetujui 14-01-2020)
}

\begin{abstract}
ABSTRAK
Desa Kalibaru Manis merupakan salah satu desa yang menjadi produsen kopi robusta. Produktivitas kopi robusta di Desa Kalibaru Manis tergolong rendah yaitu 1,12 Ton/Ha. Kopi yang dihasilkan oleh Desa Kalibaru Manis memiliki kualitas yang kurang baik, karena kegiatan pasca panen yang belum sesuai standar. Produktivitas dan mutu biji kopi yang buruk menyebabkan pendapatan yang diperoleh petani rendah. Selain itu, pendapatan yang diperoleh petani kopi robusta di Desa Kalibaru Manis tidak pasti setiap tahunnya. Ketidakpastian pendapatan ini disebabkan oleh meningkatnya biaya produksi dan turunnya harga jual kopi. Penelitian ini bertujuan untuk mengetahui: 1) kelayakan finansial usahatani kopi robusta, dan 2) sensitivitas usahatani kopi robusta. Metode penentuan daerah menggunakan purposive method. Metode penelitian yang digunakan adalah metode deskriptif dan metode analitik. Metode pengambilan contoh dilakukan dengan metode Simple Random Sampling. Metode pengumpulan data dilakukan dengan wawancara, observasi, studi dokumen. Analisis data dilakukan dengan menggunakan analisis kelayakan finansial dan analisis sensitivitas. Hasil penelitian dengan tingkat suku bunga sebesar 7\% menunjukkan bahwa: 1) Usahatani kopi robusta di Desa Kalibaru Manis layak untuk diusahakan. 2) Usahatani kopi robusta di Desa Kalibaru Manis Kecamatan Kalibaru Kabupaten Banyuwangi tidak sensitif terhadap perubahan biaya produksi dan harga jual kopi.
\end{abstract}

Kata kunci: kopi robusta, kelayakan finansial, sensitivitas

ABSTRACT

Kalibaru Manis Village is one of the villages that become Robusta coffee producers. Robusta coffee productivity in Kalibaru Manis Village is classified as low that is 1.12 Tons/Ha. Coffee produced by Kalibaru Manis Village has poor quality because the post-harvest activities that have not been following the standards Poor productivity and coffee bean quality cause the income obtained by the farmers to become low. Moreover, the income obtained by robusta coffee farmers in Kalibaru Manis Village is uncertain in each year. This uncertain income is caused by the increase of production cost and the decrease of the coffee selling price. This research aimed to find out: (1) financial feasibility of robusta coffee farming, and (2) sensitivity of robusta coffee. The area determination method used purposive method. The research methods used were descriptive method and analytic method. Sample retrieval method was done by Simple Random Sampling method. Data collection method was done by interview, observation, and documentation. Data analysis was used using financial feasibility analysis and sensitivity analysis. The research results with the interest rate level of $7 \%$ showed that : 1) Robusta coffee farming in Kalibaru Manis Village was feasible to cultivate. 2) Robusta coffee farming in Kalibaru Manis Village was not sensitive toward the changes in the production cost and robusta coffee selling price.

Keywords: robusta coffee, financial feasibility, sensitivity 


\section{PENDAHULUAN}

Kopi adalah komoditas perkebunan yang berperan penting terhadap perekonomian Indonesia. Kopi yang dihasilkan Indonesia sebanyak $67 \%$ diekspor ke negara lain dan 33\% digunakan untuk kebutuhan dalam negeri (Soemarno, 2016). Terdapat dua jenis kopi yang banyak dibudidayakan di Indonesia, yaitu arabika dan robusta. Produksi kopi robusta Indonesia mencapai 90\% dan 10\% merupakan kopi arabika. Kopi robusta memiliki kualitas rasa kurang baik dibandingkan arabika, namun kopi ini tahan terhadap serangan penyakit karat daun sehingga luas lahan kopi robusta lebih luas dibandingkan arabika. Luasnya lahan tersebut menyebakan produksi kopi yang dihasilkan menjadi lebih tinggi (Rahardjo, 2017).

Produktivitas kopi jenis robusta di Indonesia dari tahun 2001 hingga 2017 hanya sebesar $689,82 \mathrm{~kg} / \mathrm{ha}$. Produktivitas tanaman kopi ini tergolong sangat rendah bila dibanding negara pesaing seperti Vietnam yang produktivitas tanaman kopinya telah mencapai $1.542 \mathrm{~kg} / \mathrm{ha} /$ tahun (Kementerian Pertanian, 2017). Peluang untuk meningkatkan produktivitas tanaman kopi Indonesia masih sangat terbuka lebar sebab Indonesia memiliki iklim tropis yang secara agronomis sangat cocok untuk pengusahaan kedua jenis tanaman kopi tersebut. Produktivitas tanaman kopi di Indonesia juga sangat berpeluang untuk ditingkatkan sebab produktivitas kopi yang dihasilkan baru mencapai sekitar 50\% dari potensi yang mampu dicapai (Sudjarmoko, 2013).

Salah satu desa sentra penghasil kopi robusta adalah Desa Kalibaru Manis Kecamatan Kalibaru Kabupaten Banyuwangi. Produksi kopi robustanya diusahakan pada dua status kepemilikan lahan, yaitu lahan milik petani sendiri dan milik perhutani (LMDH). Desa Kalibaru Manis berada pada ketinggian $430 \mathrm{~m}$ dpl, sehingga sangat cocok untuk budidaya kopi robusta. Usahatani kopi robusta ini diharapkan mampu meningkatkan taraf hidup petani kopi robusta. Produktivitas kopi robusta yang dihasilkan rendah, yaitu 1,12 ton/ha (Badan Pusat Statistik, 20162018). Produktivitas kopi tersebut tergolong rendah karena kopi yang dikelola secara intensif mampu menghasilkan sekitar 2 ton/ha. Rendahnya produktivitas kopi robusta disebabkan oleh beberapa hal, yaitu tingkat pendidikan petani yang rendah, penggunaan sarana dan prasarana produksi yang belum optimal, kondisi cuaca yang tidak menentu, dan banyaknya tanaman kopi yang sudah tua dan rusak. 
Petani menjual kopinya dalam bentuk kopi ose. Kopi ose merupakan kopi yang diolah dengan cara dikeringkan, sehingga proses pengolahannya sangat bergantung pada cuaca. Produksi kopi yang dihasilkan tidak menentu setiap tahunya akibat adanya pengaruh cuaca yang tidak menentu berupa curah hujan yang tinggi. Curah hujan yang tinggi menyebabkan bunga dan buah kopi rontok, sehingga petani harus memanen kopi lebih awal. Kondisi tersebut diperparah dengan kurangnya ketersedian tenaga kerja saat masa panen. Banyaknya buah kopi yang rontok memaksa petani untuk memungut buah kopi yang terjatuh ke tanah, sehingga mutu biji kopi rendah. Rendahnya mutu kopi juga disebabkan kegiatan pasca panen yang belum sesuai.

Rendahnya produktivitas dan mutu kopi robusta menyebabkan pendapatan petani menjadi rendah. Rendahnya pendapatan petani menimbulkan pertanyaan terkait kemampuan usahatani kopi dalam memenuhi kebutuhan ekonomi keluarga di masa mendatang, sehingga perlu dilakukan analisis kelayakan.

Usahatani kopi mengandung risiko ketidakpastian. Risiko ketidakpastian yang dihadapi diantaranya ketidakpastian harga di masa yang akan datang baik harga kopi maupun harga sarana produksi. Penelitian yang dilakukan (Wahyuni, Utama, \& Mulyasari, 2012) menyatakan bahwa usahatani kopi arabika di Desa Bandung Baru Kecamatan Kebawetan Kabupaten Kepahiang secara finansial layak untuk diusahakan, namun jika terjadi kenaikan biaya produksi sebesar $29 \%$, penurunan harga sebesar $22 \%$, maka usahatani kopi arabika tidak layak lagi untuk diusahakan.

Adanya risiko ketidakpastian harga mengakibatkan pendapatan yang petani menjadi tidak pasti, sehingga perlu dilakukan analisis sensitivitas guna mengetahui risiko ketidakpastian tersebut. Penelitian ini bertujuan untuk mengetahui kelayakan finansial dan sensitivitas usahatani kopi robusta di Desa Kalibaru Manis Kecamatan Kalibaru Kabupaten Banyuwangi.

\section{METODE PENELITIAN}

Daerah penelitian ditentukan secara sengaja di Desa Kalibaru Manis Kecamatan Kalibaru Kabupaten Banyuwangi karena merupakan desa dengan produksi kopi tertinggi di Kecamatan Kalibaru. Penelitian dilakukan mulai tanggal 15 Februari 2019 hingga 8 April 2019. Metode penelitian menggunakan metode deskriptif untuk 
menjelaskan fenomena yang ada dan metode analitik untuk menguji suatu hipotesis dan mengiterpresikannya secara lebih mendalam terkait hubunganhubungan atau korelasi. Pengambilan contoh dilakukan dengan metode Simple Random Sampling. Banyaknya sampel yang digunakan ditentukan dengan menggunakan rumus slovin dengan presentase kelonggaran sebesar $10 \%$. Sampel pada penelitian ini adalah petani kopi robusta yang tergabung dalam kelompok tani sebanyak 46 petani. Data yang digunakan berupa data primer yang diperoleh dengan wawancara dan observasi, serta data sekunder yang diperoleh dengan studi dokumen yang kemudian dianalisis menggunakan analisis kelayakan finansial dan sensitivitas.

Analisis kelayakan dilakukan dengan melihat aspek finansial usahatani kopi robusta yang menyangkut biaya investasi, modal kerja, biaya operasi dan pemeliharaan serta perhitungan pendapatan yang mungkin diterima oleh petani. Berdasarkan perhitungan cost dan benefit akan dibahas mengenai analisis kelayakan finansial menggunakan kriteria investasi Net Present Value (NPV), Net Benefit Cost Ratio (Net B/C), Internal Rate of Return (IRR), dan Payback Period
(PP) (Soetriono, 2015). Penelitian ini dilakukan dengan tujuan untuk melakukan evaluasi proyek dan perencanaan kedepan, sehingga analisis kelayakan finansial akan dilakukan selama kurun waktu 20 tahun yaitu dari tahun 2011 hingga 2030. Tingkat suku bunga yang digunakan pada penelitian ini adalah tingkat suku bunga Kredit Usaha Rakyat (KUR) di Bank Rakyat Indonesia (BRI) pada tahun 2018, yaitu sebesar 7\% (Bank Rakyat Indonesia, 2018).

\section{Net Present Value (NPV)}

Menurut (Soetriono, 2015), Net Present Value (NPV) adalah kriteria investasi yang banyak digunakan untuk mengukur apakah suatu proyek feasible atau tidak untuk dilakukan. Perhitungan NPV dihitungan dengan menggunakan Net benefit yang telah didiskon dengan menggunakan Social Opportunity Cost of Capital (SOCC) sebagai discount factor. Secara singkat, formula perhitungan $\mathrm{Net}$ Present Value (NPV) adalah sebagai berikut:

$$
\mathrm{NPV}=\sum_{\mathrm{t}=1}^{\mathrm{n}} \frac{\mathrm{bt}-\mathrm{ct}}{(1+\mathrm{i})^{\mathrm{t}}}
$$

Keterangan:

NPV : Net Present Value

bt : Benefit (penerimaan) bersih tahun $\mathrm{t}$

ct : Cost (biaya) pada tahun $\mathrm{t}$ 
i : Suku bunga Kredit Usaha Rakyat (KUR) Bank BRI tahun 2018 (7\%)

n : Umur ekonomis proyek (20 tahun)

Kriteria Pengambilan Keputusan:

a. NPV $>0$ (NPV positif), artinya usahatani kopi robusta layak untuk diusahakan.

b. $\mathrm{NPV}=0$ (NPV netral), artinya usahatani kopi robusta berada pada kondisi impas (BEP).

c. NPV $<0$ (NPV negatif), artinya usahatani kopi robusta tidak layak untuk diusahakan.

\section{Net Benefit Cost Ratio (Net B/C)}

Net benefit cost ratio $($ Net $\mathrm{B} / \mathrm{C})$ merupakan perbandingan antara jumlah Net benefit yang telah di discount positif $(+)$ dengan jumlah Net benefit yang telah di discount negatif (-). Cara perhitungan Net $\mathrm{B} / \mathrm{C}$ adalah sebagai berikut (Soetriono, 2015):

$$
\text { Net } \mathrm{B} / \mathrm{C}=\frac{\sum_{\mathrm{i}=1}^{\mathrm{n}} \text { Net benefit }(+)}{\sum_{\mathrm{i}=1}^{\mathrm{n}} \text { Net benefit }(-)}
$$

Keterangan:

Net B/C $\quad$ : Net Benefit Cost Ratio

Net benefit $(+)$ : Net benefit yang telah di discount positif $(+)$

Net benefit (-) : Net benefit yang telah di discount positif (-)

$$
\begin{array}{ll}
\mathrm{N} & : \text { Tahun }(20 \text { tahun }) \\
\mathrm{i} & : \text { Suku bunga Kredit }
\end{array}
$$

Usaha Rakyat Bank BRI tahun 2018 (7\%).
Kriteria Pengambilan Keputusan:

a. Net $\mathrm{B} / \mathrm{C}>1$, artinya usahatani kopi robusta layak untuk diusahakan.

b. Net $\mathrm{B} / \mathrm{C}=1$, artinya usahatani kopi robusta berada pada kondisi impas (BEP)

c. Net $\mathrm{B} / \mathrm{C}<1$, artinya usahatani kopi robusta tidak layak untuk diusahakan.

3. Internal Rate of Return (IRR)

Internal rate of return (IRR) adalah suatu tingkat discount rate yang menghasilkan NPV sama dengan 0 (nol). IRR digunakan untuk mengetahui persentase keuntungan dari usaha (proyek) tiap-tiap tahun dan merupakan alat ukur kemampuan proyek dalam mengembalikan bunga pinjaman. Cara perhitungan Internal Rate of Return (IRR) adalah sebagai berikut (Soetriono, 2015):

$$
\mathrm{IRR}=\mathrm{i}^{+}+\frac{\mathrm{NPV}^{+}}{\mathrm{NPV}^{+}-\mathrm{NPV}^{-}}\left(\mathrm{i}^{-}-\mathrm{i}^{+}\right)
$$

Keterangan:

IRR : Internal Rate of Return

NPV+ : NPV positif (Rp)

NPV- : NPV negatif (Rp)

$i^{+} \quad$ : Tingkat bunga pada NPV+ $(\%)$

$i-\quad$ : Tingkat bunga pada NPV_(\%)

Kriteria Pengambilan Keputusan:

a. IRR $>7 \%$, artinya usahatani kopi robusta layak untuk diusahakan. 
b. $\operatorname{IRR}=7 \%$, artinya usahatani kopi robusta berada pada kondisi impas (BEP).

c. IRR $<7 \%$, artinya usahatani kopi robusta tidak layak untuk diusahakan.

\section{Payback Period}

Payback period (PP) adalah jangka waktu tertentu yang menunjukkan terjadinya arus penerimaan secara komulatif sama dengan jumlah investasi dalam bentuk present value. Cara perhitungan Payback Period (PP) adalah sebagai berikut (Soetriono, 2015):

$$
\mathrm{PP}=\frac{\text { Investasi }}{\text { Jumlah Net Benefit / } \mathrm{n} \text { tahun }}
$$

Keterangan:

\section{PP : Payback Period}

n : Umur ekonomis proyek (20 tahun)

Kriteria Pengambilan Keputusan:

a. $\mathrm{PP}<20$ tahun, artinya usahatani kopi robusta layak untuk diusahakan.

b. PP $>20$ tahun, artinya usahatani kopi robusta tidak layak untuk diusahakan.

\section{Analisis kepekaan (sensitivity} analysis) usahatani kopi robusta dilakukan dengan meningkatkan biaya produksi dan menurunkan harga jual kopi robusta. Terdapat dua analisis yang akan dilakukan pada penelitian ini, yaitu: meningkatkan biaya produksi sebesar $29 \%$, (b) menurunkan harga jual kopi robusta sebesar $22 \%$.
Kriteria pengambilan keputusan:

a. Apabila perubahan biaya produksi dan harga jual kopi robusta merubah nilai NPV, Net B/C, IRR, dan PP sampai kriteria tidak layak dalam analisis finansial, maka usahatani kopi robusta peka terhadap kondisi perubahan biaya produksi dan harga jual kopi robusta.

b. Apabila perubahan biaya produksi dan harga jual kopi robusta merubah nilai NPV, Net B/C, IRR, dan PP tetap masih dalam kriteria layak dalam analisis finansial, maka usahatani kopi robusta tidak peka terhadap kondisi perubahan biaya produksi dan harga jual kopi robusta.

\section{HASIL DAN PEMBAHASAN}

\section{Analisis Kelayakan Usahatani Kopi Robusta di Desa Kalibaru Manis Kecamatan Kalibaru Kabupaten Banyuwangi}

Analisis kelayakan finansial usahatani kopi robusta di Desa Kalibaru Manis dilakukan untuk mengidentifikasi biaya dan benefit guna melihat layak tidaknya usahatani kopi robusta diusahakan. Identifikasi biaya terdiri dari biaya investasi, reinvestasi, tetap, dan variabel. Identifikasi biaya digunakan untuk mengelompokkan jenis-jenis biaya yang digunakan selama usahatani kopi berlangsung. Biaya investasi usahatani 
kopi robusta merupakan biaya yang dikeluarkan pada saat awal melakukan usahatani kopi robusta.

Tabel 1. Biaya Investasi Usahatani Kopi Robusta di Desa Kalibaru Manis Kecamatan Kalibaru Kabupaten Banyuwangi Tahun 2011

\begin{tabular}{clr}
\hline No & \multicolumn{1}{c}{$\begin{array}{c}\text { Sarana dan } \\
\text { Prasarana }\end{array}$} & $\begin{array}{r}\text { Biaya Investasi } \\
\text { (Rp) }\end{array}$ \\
\hline 1 & Bibit & $792.184,23$ \\
2 & Cangkul & $25.000,00$ \\
3 & Gergaji & $20.000,00$ \\
4 & Gunting pangkas & 0,00 \\
5 & Sabit & $10.000,00$ \\
6 & Panjang & $10.000,00$ \\
7 & Terpal & 0,00 \\
8 & Mesin semprot & $250.000,00$ \\
9 & Karung kopi & 0,00 \\
10 & Pajak & $354.497,80$ \\
11 & Biaya pupuk & $1.548 .150,73$ \\
12 & Biaya obat & $185.589,67$ \\
13 & Biaya tenaga kerja & $13.575 .000,00$ \\
14 & Biaya penggilingan & 0,00 \\
15 & Biaya transportasi & $832.934,78$ \\
\hline & Total & $\mathbf{1 7 . 6 0 3 . 3 5 7 , 2 2}$ \\
\hline
\end{tabular}

Sumber: Data Primer diolah (2019)

Biaya investasi yang dikeluarkan pada awal melakukan usahatani kopi robusta adalah Rp17.603.357,22. Seluruh biaya investasi ini dikeluarkan secara tunai pada awal kegiatan usahatani kopi robusta dilakukan. Barang yang diinvestasikan pada usahatani kopi robusta memiliki umur ekonomis yang berbeda-beda. Setelah melewati umur ekonomisnya, masing-masing barang akan mengalami kerusakan maupun ketidakoptimalan kinerja sehingga dapat menghambat jalannya usaha. Barangbarang investasi yang sudah tidak dapat digunakan harus segera diganti dengan yang baru. Pergantian barang tersebut dilakukan dengan mengeluarkan biaya reinvestasi. Adapun rincian biaya reinvestasi yang harus dikeluarkan pada usahatani kopi robusta dapat dilihat pada Tabel 2.

Tabel 2. Biaya Reinvestasi Usahatani Kopi Robusta di Desa Kalibaru Manis Kecamatan Kalibaru Kabupaten Banyuwangi

\begin{tabular}{cccccc}
\hline No & Tahun & Total Biaya Tetap (Rp) & No & Tahun & Total Biaya Tetap (Rp) \\
\hline 1 & 2012 & $32.142,86$ & 11 & 2022 & $1.108,142,86$ \\
2 & 2013 & $689.428,57$ & 12 & 2023 & $429.428,57$ \\
3 & 2014 & $147.142,86$ & 13 & 2024 & $211.428,57$ \\
4 & 2015 & $170.571,43$ & 14 & 2025 & $1.262 .000,00$ \\
5 & 2016 & $1.151 .857,14$ & 15 & 2026 & $956.142,86$ \\
6 & 2017 & $339.571,43$ & 16 & 2027 & $539.571,43$ \\
7 & 2018 & $148.000,00$ & 17 & 2028 & $1.239 .428,57$ \\
8 & 2019 & $975.714,29$ & 18 & 2029 & $587.142,86$ \\
9 & 2020 & $253.428,57$ & 19 & 2030 & $274.857,14$ \\
10 & 2021 & $774.714,29$ & & & \\
\hline
\end{tabular}

Sumber: Data Primer diolah (2019)

Biaya reinvestasi yang dikeluarkan oleh usahatani kopi robusta berbeda setiap tahunnya karena didasarkan pada jumlah barang yang perlu diganti. Biaya investasi terbesar dikeluarkan pada tahun 2025 yaitu Rp1.262.000,00. Biaya investasi tersebut digunakan untuk membeli sabit, panjang, terpal dan karung kopi.

Biaya tetap pada usahatani kopi robusta merupakan biaya yang jumlahnya 
tidak tergantung atas besar kecilnya kuantitas produksi kopi robusta yang dihasilkan. Biaya tetap yang dikeluarkan meliputi biaya cukai yang di bayarkan kepada pihak perhutani. Biaya cukai yang dikeluarkan berupa produk olahan kopi ose sebanyak $20 \mathrm{~kg}$ kopi ose per hektarnya atau diganti dengan uang yang setara. Rincian biaya tetap yang dikeluarkan oleh petani kopi robusta di Desa Kalibaru Manis dapat dilihat pada Tabel 3.

Tabel 3. Biaya Tetap Usahatani Kopi Robusta di Desa Kalibaru Manis Kecamatan Kalibaru Kabupaten

\begin{tabular}{cccccc}
\multicolumn{7}{c}{ Banyuwangi } & & & \\
\hline No & Tahun & Total Biaya Tetap (Rp) & No & Tahun & Total Biaya Tetap (Rp) \\
\hline 1 & 2011 & $354.497,80$ & 11 & 2021 & $558.422,53$ \\
2 & 2012 & $391.599,60$ & 12 & 2022 & $586.997,27$ \\
3 & 2013 & $394.733,20$ & 13 & 2023 & $608.040,36$ \\
4 & 2014 & $382.746,80$ & 14 & 2024 & $632.029,10$ \\
5 & 2015 & $422.809,40$ & 15 & 2025 & $651.399,53$ \\
6 & 2016 & $431.863,20$ & 16 & 2026 & $671.802,69$ \\
7 & 2017 & $467.686,00$ & 17 & 2027 & $699.906,55$ \\
8 & 2018 & $515.797,60$ & 18 & 2028 & $722.990,49$ \\
9 & 2019 & $509.197,94$ & 19 & 2029 & $744.690,33$ \\
10 & 2020 & $530.217,53$ & 20 & 2030 & $766.659,05$ \\
\hline
\end{tabular}

Sumber: Data Primer diolah (2019)

Biaya cukai yang dikeluarkan usahatani kopi robusta berbeda-beda setiap tahunnya karena dipengaruhi oleh harga kopi yang selalu berubah setiap tahunnya. Biaya tetap tertinggi dikeluarkan pada tahun 2030 yaitu Rp766.659,05, karena harga kopi pada tahun tersebut merupakan harga kopi tertinggi yaitu Rp38.332,95/kg.

Biaya variabel usahatani kopi robusta merupakan biaya yang jumlahnya tergantung pada skala produksi yang digunakan oleh petani. Biaya variabel pada usahatani kopi robusta meliputi biaya pupuk, biaya obat-obatan pertanian, biaya tenaga kerja, biaya penggilingan kopi robusta, dan biaya transportasi. Biaya variabel yang dikeluarkan oleh petani kopi robusta di Desa Kalibaru Manis dapat dilihat pada Tabel 4.

Berdasarkan Tabel 4 dapat diketahui bahwa biaya variabel yang dikeluarkan usahatani kopi robusta setiap tahunnya berbeda. Biaya variabel terbesar dikeluarkan pada tahun 2030, yaitu Rp19.670.552,15. Seluruh biaya yang dikeluarkan oleh petani selanjutnya dapat dimasukkan ke dalam outflow untuk mengetahui keseluruhan biaya untuk melaksanakan usahatani kopi robusta. 
Tabel 4. Biaya Variabel Usahatani Kopi Robusta di Desa Kalibaru Manis Kecamatan Kalibaru Kabupaten Banyuwangi

\begin{tabular}{cccccc}
\hline No & Tahun & Total Biaya Variabel (Rp) & No & Tahun & Total Biaya Variabel (Rp) \\
\hline 1 & 2011 & $16.141 .675,19$ & 11 & 2021 & $14.823 .084,50$ \\
2 & 2012 & $5.003 .553,13$ & 12 & 2022 & $15.511 .270,15$ \\
3 & 2013 & $9.202 .327,81$ & 13 & 2023 & $15.864 .886,36$ \\
4 & 2014 & $9.815 .712,84$ & 14 & 2024 & $16.639 .716,19$ \\
5 & 2015 & $10.488 .765,40$ & 15 & 2025 & $16.898 .420,30$ \\
6 & 2016 & $11.229 .419,13$ & 16 & 2026 & $17.370 .704,71$ \\
7 & 2017 & $12.098 .539,45$ & 17 & 2027 & $17.835 .698,52$ \\
8 & 2018 & $13.223 .016,31$ & 18 & 2028 & $18.560 .190,21$ \\
9 & 2019 & $13.718 .079,70$ & 19 & 2029 & $18.927 .965,27$ \\
10 & 2020 & $14.692 .409,74$ & 20 & 2030 & $19.670 .552,15$ \\
\hline
\end{tabular}

Sumber: Data Primer diolah (2019)

Petani kopi robusta memperoleh penerimaan dari penjualan kopi robusta. Harga jual kopi robusta setiap tahunnya berbeda. Penerimaan pada usahatani kopi robusta di Desa Kalibaru Manis dapat dicermati pada Tabel 5.

Tabel 5. Penerimaan Usahatani Kopi Robusta di Desa Kalibaru Manis Kecamatan Kalibaru Kabupaten

\begin{tabular}{cccccc}
\multicolumn{7}{c}{ Banyuwangi } & & & \\
\hline No & Tahun & Penerimaan (Rp) & No & Tahun & Penerimaan (Rp) \\
\hline 1 & 2011 & 0,00 & 11 & 2021 & $36.297 .464,76$ \\
2 & 2012 & 0,00 & 12 & 2022 & $39.622 .315,44$ \\
3 & 2013 & $4.934 .165,00$ & 13 & 2023 & $34.962 .320,84$ \\
4 & 2014 & $6.698 .069,00$ & 14 & 2024 & $39.501 .818,76$ \\
5 & 2015 & $10.570 .235,00$ & 15 & 2025 & $32.569 .976,61$ \\
6 & 2016 & $15.115 .212,00$ & 16 & 2026 & $30.231 .121,10$ \\
7 & 2017 & $23.384 .300,00$ & 17 & 2027 & $27.996 .262,03$ \\
8 & 2018 & $38.684 .820,00$ & 18 & 2028 & $30.727 .095,78$ \\
9 & 2019 & $35.643 .856,00$ & 19 & 2029 & $26.064 .161,41$ \\
10 & 2020 & $45.068 .489,93$ & 20 & 2030 & $28.749 .714,45$ \\
\hline
\end{tabular}

Sumber: Data Primer diolah (2019)

Berdasarkan Tabel 5 dapat diketahui bahwa usahatani kopi robusta memperoleh penerimaan terbesar pada tahun 2020, yaitu Rp45.068.489,93 akibat produksi kopi yang lebih tinggi dibandingkan dengan produksi kopi pada tahun-tahun lainnya. Usahatani kopi robusta belum memperoleh penerimaan pada tahun 2011 dan 2012, karena tanaman kopi robusta belum berbuah atau berproduksi. Penerimaan pada usahatani kopi robusta dari tahun 2013 hingga 2020 cenderung mengalami peningkatan, namun pada tahun 2021 hingga 2030 cenderung mengalami penurunan karena produksi kopi pada usia 3 hingga 10 tahun akan terus meningkat, namun setelah berusia lebih dari 10 tahun produksi kopi akan menurun. Penerimaan usahatani kopi robusta kemudian dimasukkan dalam cashflow sebagai komponen dari inflow untuk mengetahui penerimaan yang diperoleh usahatani kopi robusta selama umur ekomisnya yaitu 20 tahun. 
Kriteria investasi yang digunakan untuk mengukur kelayakan usahatani kopi robusta meliputi analisis Net Present Value (NPV), Net Benefit Cost Ratio (Net B/C), Internal Rate of Return (IRR), dan Payback Period (PP). Tingkat suku bunga atau discount rate yang digunakan adalah $7 \%$ yang diambil dari suku bunga Kredit
Usaha Rakyat (KUR) di Bank Rakyat Indonesia (BRI) pada tahun 2018. Usahatani kopi robusta dapat terus diusahakan apabila memenuhi syarat kelayakan dari seluruh kriteria investasi. Hasil analisis kelayakan usahatani kopi robusta dapat dilihat pada Tabel 6 .

Tabel 6. Hasil Analisis Kelayakan Usahatani Kopi Robusta di Desa Kalibaru Manis Kecamatan Kalibaru Kabupaten Banyuwangi Tahun 2011-2030

\begin{tabular}{clrcc}
\hline No & Kriteria Investasi & \multicolumn{1}{c}{ Nilai } & Indikator & Keterangan \\
\hline 1 & NPV & Rp $78.984 .296,43$ & $>0$ & Layak \\
2 & Net BC & 3,571 & $>1$ & Layak \\
3 & IRR & $23,24 \%$ & $>7 \%$ & Layak \\
4 & PP & 4,56 Tahun & $<20$ Tahun & Layak \\
\hline
\end{tabular}

Sumber: Data Primer diolah (2019)

Berdasarkan Tabel 6. dapat diketahui bahwa hasil perhitungan NPV pada usahatani kopi robusta di Desa Kalibaru Manis selama kurun waktu 20 tahun (tahun 2011-2030) memiliki nilai NPV positif sebesar Rp78.984.296,43. Nilai NPV tersebut menunjukkan bahwa usahatani kopi robusta layak untuk diusahakan karena nilai NPV lebih dari 0. Berdasar nilai tersebut dapat diartikan bahwa bahwa nilai investasi yang telah ditanamkan sekarang maka pada 3 tahun mendatang akan memberikan keuntungan sebesar Rp78.984.296,43 dengan tingkat suku bunga sebesar 7\%. Hasil perhitungan tersebut menunjukkan bahwa usahatani kopi robusta mampu memberikan manfaat bagi petani kopi robusta, namun masih rendah. Penerimaan ini diperoleh karena produksi kopi yang dihasilkan kurang baik, karena kondisi cuaca yang tidak menentu dan pemeliharaan yang kurang baik, terutama pada kegiatan pemupukan dan pengendalian hama. Selain itu, petani biasanya langsung menjual kopinya tanpa memikirkan harga yang akan diperolehnya.

Hasil perhitungan Net $\mathrm{B} / \mathrm{C}$ pada usahatani kopi robusta dari tahun ke-0 hingga tahun ke-19 dengan tingkat suku bunga $7 \%$ adalah lebih besar dari 1, yaitu 3,571. Nilai tersebut menunjukkan bahwa usahatani kopi robusta secara nyata layak untuk diusahakan. Nilai Net $\mathrm{B} / \mathrm{C}$ sebesar 3,571 dapat diartikan bahwa usahatani kopi robusta akan mendatangkan manfaat sebesar 3,571 kali lipat dari biaya yang dikeluarkan oleh petani. Nilai tersebut 
menunjukkan bahwa usahatani kopi robusta masih bisa memberikan manfaat (benefit) yang lebih besar dibandingkan biaya yang dikeluarkan.

Nilai IRR yang diperoleh pada perhitungan kelayakan usahatani kopi robusta adalah 23,24\%. Nilai tersebut menunjukkan bahwa usahatani kopi robusta masih menguntungkan karena tingkat suku bunga tersebut lebih tinggi dari tingkat suku bunga yang berlaku (7\%), namun usahatani kopi robusta tersebut tidak akan menguntungkan lagi jika tingkat suku bunga bank mencapai 23,24\%. Nilai tersebut membuktikan bahwa berdasarkan perhitungan IRR usahatani kopi robusta layak untuk diusahakan dan mampu mengembalikan biaya investasi yang dikeluarkan pada awal melakukan usahatani kopi pada tingkat suku bunga mencapai $23,24 \%$ per tahun.

Berdasarkan Tabel 6 dapat disimpulkan bahwa usahatani kopi robusta dapat mengembalikan biaya investasinya (Payback Period) dalam kurun waktu 4,56 tahun terhitung dari tahun pertama kali investasi. Hal ini menunjukkan bahwa usahatani kopi robusta layak untuk diusahakan dengan pertimbangan bahwa usahatani tersebut mampu memperoleh kembali modal investasinya dalam kurun waktu 4,56 tahun dengan umur usahatani kopi robusta 20 tahun.

Berdasarkan penilaian menggunakan 4 kriteria kelayakan investasi, yaitu NPV sebesar Rp78.984.296,43; net B/C sebesar 3,571; IRR sebesar 23,24\% dan PP selama 4,56 tahun. Berdasarkan hasil analisis tersebut dapat disimpulkan bahwa usahatani kopi robusta secara finansial layak diusahakan. Hasil analisis kelayakan tersebut membuktikan bahwa hipotesis pertama yang diajukan pada penelitian diterima, yaitu usahatani kopi robusta di Desa Kalibaru Manis secara finansial layak untuk diusahakan.

\section{Sensitivitas Usahatani Kopi Robusta di Desa Kalibaru Manis Kecamatan Kalibaru Kabupaten Banyuwangi}

Usahatani kopi robusta dipengaruhi oleh adanya ketidakpastian, sehingga perlu dilakukan analisis sensitivitas untuk melihat kembali kelayakan usaha akibat adanya perubahan keadaan berupa perubahan biaya variabel dan harga jual kopi. Penelitian ini menggunakan perubahan keadaan berupa peningkatan biaya variabel sebesar $29 \%$ dan penurunan harga jual kopi sebesar $22 \%$ dengan parameter lain dinggap tetap. Hasil dari analisis sensitivitas diharapkan mampu menunjukkan apakah usahatani kopi 
robusta sensitif atau tidak terhadap perubahan tersebut.

Presentase peningkatan biaya produksi dan penurunan harga jual kopi robusta yang digunakan untuk menguji sensitivitas usahatani kopi robusta adalah $29 \%$ dan 22\%. Presentase tersebut didasarkan pada penelitian (Wahyuni, Utama, \& Mulyasari, 2012) yang menyatakan bahwa peningkatan biaya produksi 29\% dan penurunan harga jual $22 \%$ menyebabkan usahatani kopi arabika tidak layak untuk diusahakan, sehingga peneliti tertarik untuk melakukan analisis sensitivitas dengan meningkatkan biaya produksi 29\% dan menurunkan harga jual kopi $22 \%$ dengan tujuan mengetahui kelayakan usahatani ketika terjadi perubahan tersebut. Hasil perhitungan $\mathrm{NPV}$, Net B/C, IRR dan PP dengan peningkatan biaya produksi dan penurunan harga jual kopi robusta terdapat pada Tabel 7.

Tabel 7. Perbandingan Kelayakan Finansial dan Sensitivitas Kelayakan Usahatani Kopi Robusta di Desa Kalibaru Manis Kecamatan Kalibaru Kabupaten Banyuwangi Tahun 2011-2030

\begin{tabular}{|c|c|c|c|c|c|}
\hline No & Kondisi & Kriteria Investasi & Nilai & Indikator & Keterangan \\
\hline \multirow[t]{4}{*}{1} & Normal & NPV & Rp 78.984.296,43 & $>0$ & Layak \\
\hline & & Net BC & 3,571 & $>1$ & Layak \\
\hline & & IRR & $23,24 \%$ & $>7 \%$ & Layak \\
\hline & & $\mathrm{PP}$ & 4,56 & $<20$ Tahun & Layak \\
\hline \multirow[t]{4}{*}{2} & Peningkatan & NPV & Rp 35.943.291,49 & $>0$ & Layak \\
\hline & Biaya Produksi & Net BC & 1,809 & $>1$ & Layak \\
\hline & $29 \%$ & IRR & $14,55 \%$ & $>7 \%$ & Layak \\
\hline & & PP & 5,01 Tahun & $<20$ Tahun & Layak \\
\hline \multirow[t]{4}{*}{3} & Penurunan & NPV & Rp 25.919.832,83 & $>0$ & Layak \\
\hline & Harga Kopi 22\% & Net BC & 1,733 & $>1$ & Layak \\
\hline & & IRR & $14,03 \%$ & $>7 \%$ & Layak \\
\hline & & $\mathrm{PP}$ & 5,02 Tahun & $<20$ Tahun & Layak \\
\hline
\end{tabular}

Sumber: Data Primer diolah (2019)

Berdasarkan Tabel 7 terlihat bahwa hasil kriteria investasi pada kondisi normal, terjadi peningkatan biaya produksi 29\% dan penurunan harga jual kopi robusta $22 \%$ sangat jelas berbeda. Peningkatan biaya produksi sebesar 29\% dapat menurunkan nilai NPV yang awalnya Rp78.984.296,43 menjadi Rp35.943.291,49, sedang penurunan harga jual kopi robusta $22 \%$ menurunkan nilai NPV menjadi Rp25.919.832,83. Penurunan tersebut masih membuat NPV bernilai positif. NPV yang bernilai positif berarti nilai NPV lebih dari 0 dan dapat disimpulkan usahatani kopi robusta di Desa Kalibaru Manis masih layak untuk diusahakan.

Peningkatan biaya produksi $29 \%$ dan penurunan harga jual kopi robusta $22 \%$ juga mempengaruhi nilai net $\mathrm{B} / \mathrm{C}$ 
yang awalnya 3,571 menjadi 1,809. Penurunan harga jual kopi robusta $22 \%$ juga membuat nilai net $\mathrm{B} / \mathrm{C}$ turun menjadi 1,733. Peningkatan biaya produksi dan penurunan harga jual kopi robusta ini masih membuat nilai net $\mathrm{B} / \mathrm{C}$ lebih dari 1 , artinya usahatani kopi robusta di Desa Kalibaru Manis masih layak untuk diusahakan.

Peningkatan biaya produksi sebesar $29 \%$ juga mempengaruhi nilai IRR yang awalnya $23,24 \%$ menjadi $14,55 \%$, sedang nilai IRR dengan penurunan harga jual kopi robusta $22 \%$ adalah sebesar $14,03 \%$. Artinya, ketika terjadi peningkatan biaya produksi sebesar 29\% dan penurunan harga jual kopi robusta $22 \%$ usahatani kopi robusta di Desa Kalibaru Manis tergolong layak diusahakan dan mampu mengembalikan biaya investasi yang dikeluarkan pada awal melakukan usahatani kopi. Hal ini dikarenakan nilai IRR masih lebih besar daripada tingkat suku bunga yang digunakan, yaitu sebesar $7 \%$.

Peningkatan biaya produksi $29 \%$ dan penurunan harga jual kopi robusta $22 \%$ mempengaruhi nilai PP usahatani kopi robusta. Nilai PP dalam kondisi peningkatan biaya produksi sebesar $29 \%$ adalah 5,01 Tahun dimana waktu pengembalian tersebut menjadi lebih lama daripada ketika berada pada kondisi normal yaitu 4,56 Tahun, sedang penurunan harga jual kopi robusta $22 \%$ merubah nilai PP menjadi 5,02 Tahun. Nilai PP tersebut menunjukkan bahwa usahatani kopi robusta di Desa Kalibaru Manis layak untuk diusahakan dengan pertimbangan bahwa usahatani kopi robusta mampu memperoleh kembali modal investasinya kurang dari umur usahatani kopi robusta (20 tahun).

Adanya peningkatan biaya produksi $29 \%$ dan penurunan harga jual kopi $22 \%$ akan mempengaruhi nilai $\mathrm{NPV}$, net $\mathrm{B} / \mathrm{C}$, IRR dan PP pada usahatani kopi robusta. Nilai perubahan pada setiap kriteria kelayakan NPV, net $\mathrm{B} / \mathrm{C}$, dan IRR pada peningkatan biaya produksi $29 \%$ dan penurunan harga jual kopi robusta $22 \%$ masih menunjukkan bahwa usahatani kopi robusta di Desa Kalibaru Manis masih layak untuk diusahakan dengan tingkat pengembalian modal yang lebih lama dari keadaan normal.

\section{KESIMPULAN DAN SARAN}

Berdasarkan hasil penelitian dan pembahasan, maka dapat ditarik kesimpulan sebagai berikut:

1. Usahatani kopi robusta di Desa Kalibaru Manis layak untuk diusahakan dengan nilai NPV selama 
kurun waktu 20 tahun positif, yaitu Rp78.984.296,43; dengan net B/C lebih tinggi dari $1(3,571)$; IRR lebih tinggi dari tingkat suku bunga (7\%) yaitu 23,24\%; dan PP lebih lama dari umur ekonomis usahatani kopi (20 tahun) yaitu 4,56 tahun.

2. Hasil analisis menunjukkan bahwa usahatani kopi robusta di Desa Kalibaru Manis Kecamatan Kalibaru Kabupaten Banyuwangi tidak sensitif terhadap perubahan peningkatan biaya produksi sebesar $29 \%$ dan penurunan harga jual kopi robusta sebesar $22 \%$.

Berdasarkan kesimpulan di atas maka dapat disarankan sebagai berikut:

1. Berdasarkan nilai NPV dapat diketahui bahwa pendapatan yang diterima petani tergolong rendah, oleh karena itu petani sebaiknya meningkatkan produktivitas dan mutu biji kopi untuk meningkatkan pendapatan melalui penggunaan pupuk yang tepat, pengendalian hama dan penyakit secara maksimal, pemanenan dan pengolahan tepat waktu.

2. Untuk mempertahankan kelayakan usahatani kopi robusta alangkah baiknya petani menjual kopinya secara berkelompok untuk meningkatkan harga jual kopi dan menggunakan pupuk kandang dan pupuk bersubsidi untuk menekan jumlah biaya.

\section{DAFTAR PUSTAKA}

Badan Pusat Statistik. (2016-2018). Kecamatan Kalibaru dalam Angka. Banyuwangi: Badan Pusat Statistik Kabupaten Banyuwangi.

Bank Rakyat Indonesia. (2018, 12 20). Kredit Usaha Rakyat. Diambil kembali dari Bank BRI: https://bri.co.id/kur

Kementerian Pertanian. (2017). Outlook Kopi Komoditas Pertanian Subsektor Perkebunan. Jakarta: Pusat Data dan Sistem Informasi Pertanian Sekretariat Jenderal Kementrian Pertanian.

Rahardjo, P. (2017). Berkebun Kopi. Jakarta: Penebar Swadaya.

Soemarno, M. R. (2016). Pengelolaan Lahan untuk Kebun Kopi. Malang: Gunung Samudera.

Soetriono. (2015). Daya Saing Agribisnis Kopi Robusta (Sebuah Perspektif Ekonomi). Malang: Bayumedia Publishing.

Sudjarmoko, B. (2013). Prospek Pengembangan Industrialisasi Kopi Indonesia. SIRINOV, 99-110.

Wahyuni, S. S., Utama, S. P., \& Mulyasari, G. (2012). Analisis Kelayakan Finansial Usahatani Kopi Arabika di Desa Bandung Baru Kecamatan Kebawetan Kabupaten Kepahiang. Agrisep, 4530 . 